AWEJ for Translation \& Literary Studies, Volume3, Number3. August 2019

DOI: http://dx.doi.org/10.24093/awejtls/vol3no3.1

Pp. 3-19

\title{
When Translation Becomes a Question of Intervention
}

\author{
Wafaa Bedjaoui \\ Department of Translation, Faculty of Languages \\ Princess Nourah bint Abdulrahman University \\ Riyadh, Saudi Arabia \\ Amina Tahraoui \\ Department of Translation, Faculty of Languages \\ Princess Nourah bint Abdulrahman University \\ Riyadh, Saudi Arabia
}

\begin{abstract}
This article attempts to highlight the social, political, and ethical challenges facing the translator when dealing with religious and philosophical texts. Drawing on our experience in translating books related to these fields from Arabic into French and vice versa, we pinpoint examples of untranslatability of some religious and intellectual concepts due to constraints within the target language. Moreover, the question of the translator as cross-cultural mediator capable of achieving acculturation is addressed. The analysis is conducted following two fundamental concepts in the field of translation studies, namely domestication and foreignization, in addition to another view commonly used by the French philosopher Michel Foucault "authority or power of language" which arises through the discourses that we produce, or that others produce. These ideas will give insights into the translators' choices, decisions, and even hesitations when handling terms or expressions connected with religious or intellectual concepts.
\end{abstract}

Keywords: domestication, foreignization, ideology, religious concepts, untranslatability

Cites as: Bedjaoui, W., \& Tahraoui, A. (2019). When Translation Becomes a Question of Intervention. Arab World English Journal for Translation \& Literary Studies, 3 (3) 3-19. DOI: http://dx.doi.org/10.24093/awejtls/vol3no3.1 


\section{Introduction}

The debate among translation theorists is still based on problematic issues that appear to be already tackled. Plenty of questions are raised continuously about classical translation issues, such as "faithfulness" that has ended in some dichotomies including foreignization and domestication. These concepts are currently one of the most widely known and refer to those translation strategies, where the translator either complies with the source text's specific properties and brings them to the target text and audience, or excludes them as much as possible and gets closer to the target language.

This controversy between source text and target text's proponents only reflects the "Self" and "Other" polarity. As soon as we comprehend the translator's position from each of them, we recognize translation as a complex interactional intellectual process made up of choices, resulting from several beliefs and opinions that build the translator's personality.

Accordingly, the present paper attempts to highlight the social, political, and ethical challenges facing the translator, through our experience in translating books from French into Arabic and vice versa. We consider some examples where it might be impossible to translate the concepts due to the target language limitedness. In the end, an attempt is made to provide an answer to the question of whether the translator -as a cultural mediator - can achieve acculturation.

This contribution is the continuation of a reflection already started two years ago on the translation of philosophical and religious texts from French into Arabic and vice versa. Bedjaoui (2018) has stressed the relativity of the translating process when it comes to specialized concepts in sensitive areas. Being especially careful when interpreting the terms related to the management of human relations, and tolerance towards the Other is the greatest challenge that the translator may face.

\section{Theoretical Background}

The topic addressed in the 4th Forum for Arab and International Relations1 is tightly linked to the Arab Islamic identity with all its dimensions, and tackling such issues requires objectivity, because talking about culture and acculturation leads to discussion about mutual influence between Arabs and the Western World.

It is commonly agreed among translation theorists, professional translators or academics that translation is a human communicative act which may hide mines, if realized for propaganda or distorting purposes. Distorting translations are sometimes used for political speeches, such as the speech of the ex-president 'Mohamed Morsi' that has been intentionally distorted by the official Iranian channel interpreter in 20152.

To investigate the choices, decisions, and hesitations belonging to translators, two main concepts in the field of translation science previously mentioned, constitute the basis of our analysis, namely"foreignization and domestication." These terms have been introduced by Venuti (1995/2003) when discussing the translator's invisibility: 
Invisibility is the term I will use to describe the translator's situation and activity in contemporary Anglo-American culture [....] A translated text, whether prose or poetry, fiction or nonfiction, is judged acceptable by most publishers, reviewers, and readers when it reads fluently, when the absence of any linguistic or stylistic peculiarities makes it seem transparent, giving the appearance that it reflects the foreign writer's personality or intention or the essential meaning of the foreign text - the appearance, in other words, that the translation is not, in fact, a translation, but the "original". (p.1)

The two concepts "foreignization "and "domestication "have received considerable attention from translation scholars and researchers, particularly when it comes to conveying the meaning of culture-bound terms and expressions, and could be associated to a certain extent with SL oriented and TL oriented strategies. According to Venuti (1995/2003):

Foreignizing translation signifies the difference of the foreign text, yet only by disrupting the cultural codes that prevail in the target language". At the same time, domestication tends to create "the illusion of transparency, a fluent translation masquerades as true semantic equivalence when it, in fact, inscribes the foreign text with a partial interpretation [...] reducing if not simply excluding the very difference that translation is called on to convey. (pp.20-21)

Furthermore, another concept of the French philosopher "Michel Foucault "is used, namely, the power of language that arises from the discourses that we produce, or that others produce. In this context, in a reformulation of Foucault's idea about language power, Zouaoui (2002/2012) points out that the discourse is a material authority, which possesses power and entails risks and fears, as well as conflicts which may lead to victory or defeat, emancipation or enslavement. This authority goes beyond the self and the institution, and establishes itself as an independent entity, which terrifies the selves, the institutions, and the communities. For this reason, some communities, especially the western one, strive to impose various forms of control over discourse and its power 3 .

However, the notion of language power will be used out of its philosophical context, within a translational context, meaning the limits imposed by languages and discourses concerned with translation. Consequently, the translator becomes a captive and is governed by specific choices, especially in the field of human and social sciences, which deals with issues related to individuals and communities, their cultures and customs.

\section{Research Methodology and The Study Corpus}

Taking account of the definition and perception explained in the previous section, we will consider some translations we have accomplished with Algerian and Egyptian publishers (Ben Merabet Library, Dar el Houda, International Echourouk Library, and Dar el Falah ). The strategies applied to transfer our culture to others and other cultures to us will be exposed. It is worth مقالات جمعية العلماء المسلمين الجزائريين : (Essays of Algerian Muslim Scholars Association), which we have translated in $2015^{4}$, and Les 
conditions de la renaissance (Conditions of Renaissance) the book of the Algerian thinker Malek Bennabi where we translated some parts in 2016. This book was translated by the Egyptian Islamic thinker Abdessabour Shaheen as well, and after reading his version, it could be suggested that what he has accomplished is a rewriting of the original text. This leads us to make a comparison with our translation to show that the translation work is subject to the translator's conception, his ideological, and intellectual beliefs, and his political orientations, and that translation is a doubleedged sword. In this regard, it seems that the most prominent problematic issues of acculturation resulting from translation are related to Islamic Arab identity, such as religious concepts.

Having presented the theoretical framework and the corpus of our study, we provide a detailed table of all the works that we have translated, to explain the circumstances surrounding the translation process such as time and space.

Table 1. The Translated Works

\begin{tabular}{|c|c|c|c|}
\hline $\begin{array}{l}\text { Title of the book, author's } \\
\text { name, year of publication } \\
\text { and publishing house }\end{array}$ & $\begin{array}{l}\text { The publishing } \\
\text { house that has } \\
\text { initiated the } \\
\text { translation project } \\
\text { and year of } \\
\text { publication }\end{array}$ & Remarks & The Purpose from Translation \\
\hline 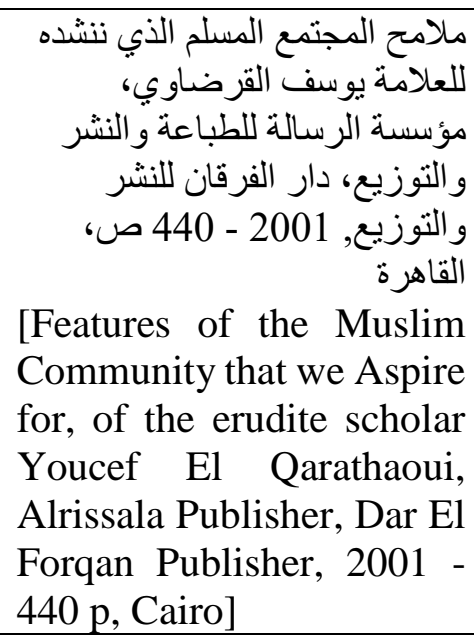 & 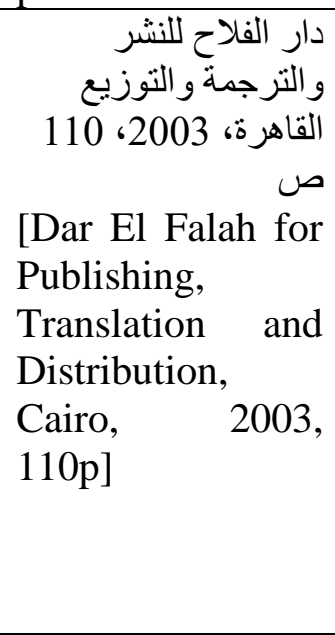 & $\begin{array}{l}\text { Translation } \\
\text { of part eleven } \\
\text { only. }\end{array}$ & $\begin{array}{l}\text { This is an attempt to clarify } \\
\text { concepts connected with the } \\
\text { woman's status in Islam, and to } \\
\text { change the Western World } \\
\text { conception about her unfortunate } \\
\text { situation in Arab and Islamic } \\
\text { societies, addressing them with } \\
\text { their language. }\end{array}$ \\
\hline 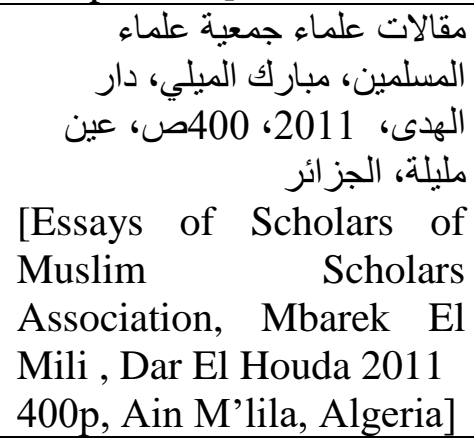 & 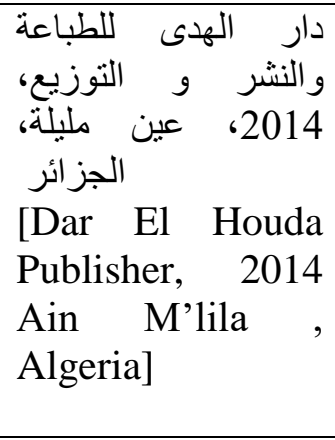 & $\begin{array}{l}\text { We have } \\
\text { translated } \\
\text { three parts, } \\
\text { and a } \\
\text { master's } \\
\text { student has } \\
\text { translated the } \\
\text { fourth one. }\end{array}$ & $\begin{array}{l}\text {-Giving an accurate picture of } \\
\text { the Algerian society between } \\
1930 \text { and } 1965 \text {. } \\
\text {-Providing other interpretations } \\
\text { to francophone historians to } \\
\text { show them history based on an } \\
\text { Algerian religious and cultural } \\
\text { reference from that period. }\end{array}$ \\
\hline
\end{tabular}


AWEJ for Translation \& Literary Studies Volume, 3 Number 3. August 2019

The Awakening of Female Consciousness in Kate Chopin's

Alajlan

\begin{tabular}{|c|c|c|c|}
\hline 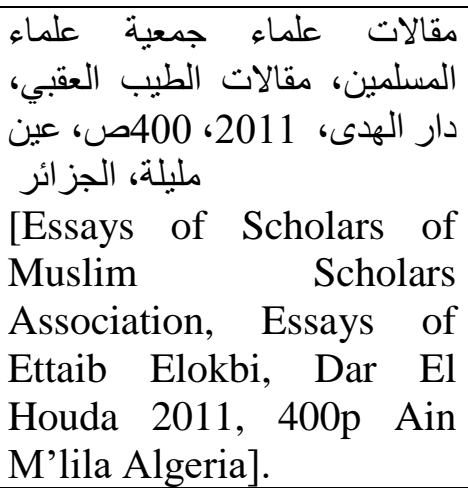 & 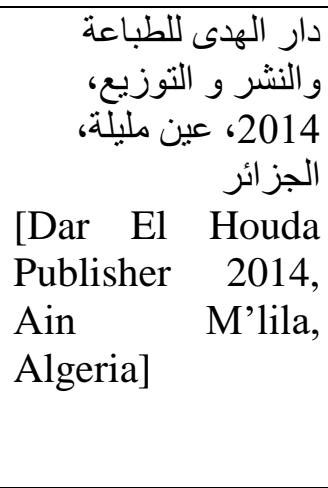 & $\begin{array}{l}\text { The same } \\
\text { remarks }\end{array}$ & The same remarks \\
\hline 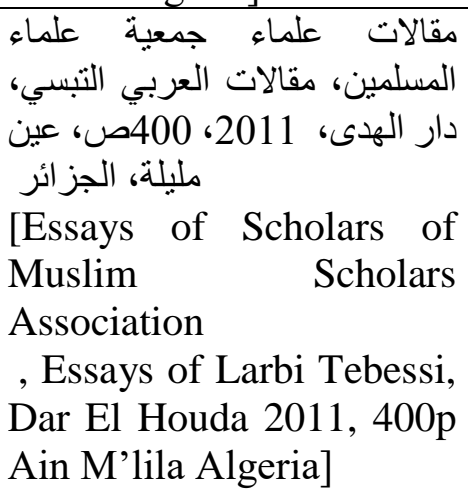 & 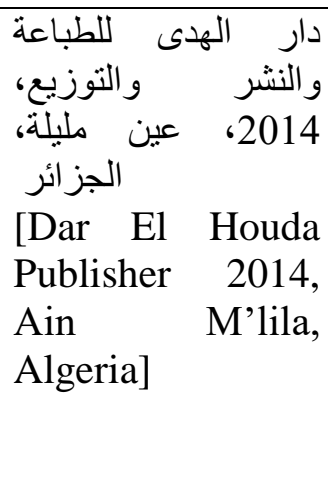 & $\begin{array}{l}\text { The same } \\
\text { remarks }\end{array}$ & The same remarks \\
\hline $\begin{array}{l}\text { The Bible and } \\
\text { Colonialism: A Moral } \\
\text { Critique, Continuum } \\
\text { International Publishing } \\
\text { Group, } 1997 \\
\text { La Bible et le colonialisme, } \\
\text { Paul Jourez, 2003, } \\
\text { L'Harmattan. }\end{array}$ & 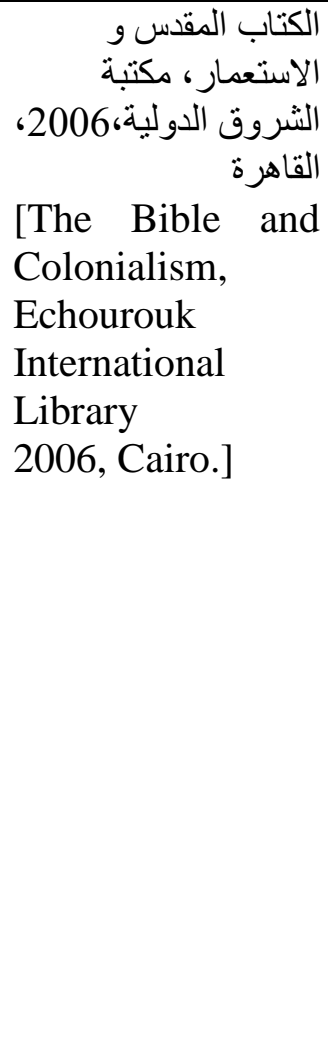 & $\begin{array}{l}\text { This book } \\
\text { was } \\
\text { published for } \\
\text { the first time } \\
\text { in English in } \\
\text { 1997, then } \\
\text { translated } \\
\text { into French in } \\
2003 \text { by Paul } \\
\text { Jourez, and } \\
\text { into Arabic in } \\
2004 \text { Ahmed } \\
\text { El Djamel } \\
\text { and Mona } \\
\text { Ziad, } \\
\text { Kodmous } \\
\text { Company for } \\
\text { Publishing } \\
\text { and } \\
\text { Distribution. } \\
\text { Our } \\
\text { translation is }\end{array}$ & $\begin{array}{l}\text { Presentation of an extremely } \\
\text { significant study about how } \\
\text { Zionists have used a biased } \\
\text { interpretation of the Torah, to } \\
\text { deprive Palestinians of their } \\
\text { territories. }\end{array}$ \\
\hline
\end{tabular}

Arab World English Journal for Translation \& Literary Studies

ISSN: 2550-1542 | www.awej-tls.org 
AWEJ for Translation \& Literary Studies Volume, 3 Number 3. August 2019

The Awakening of Female Consciousness in Kate Chopin's

Alajlan

\begin{tabular}{|c|c|c|c|}
\hline & & $\begin{array}{l}\text { based on the } \\
\text { French } \\
\text { version of the } \\
\text { book. }\end{array}$ & \\
\hline $\begin{array}{l}\text { Les conditions de la } \\
\text { renaissance «Le problème } \\
\text { de la femme »pp.123-128 } \\
\text { Malek Bennabi, 2005, } \\
\text { ANEP } \\
\text { [Conditions of the } \\
\text { Renaissance "the woman's } \\
\text { issue"pp.123-128] }\end{array}$ & $\begin{array}{l}\text { دار بن مر ابط للنشر } \\
\text { [Dar Ben Merabet } \\
\text { Publisher] }\end{array}$ & $\begin{array}{l}\text { Also } \\
\text { published by } \\
\text { Syrian Dar El } \\
\text { Fikr in } 1957 \\
\text { based on the } \\
\text { first edition } \\
\text { of } 1948 \text {. }\end{array}$ & $\begin{array}{l}\text { Revival of the intellectual } \\
\text { heritage of Malek Bennabi. }\end{array}$ \\
\hline
\end{tabular}

As seen from the table, The French version of Conditions de la renaissance (Conditions of Renaissance) was issued for the first time in 1948, and translated in 1957 by the Syrian publishing company "Dar el Fikr". It is characterized by a philosophical language, as it addresses questions related to civilization, society, and culture. The author, who sheds light on the causes of Muslims' decline:

was a Muslim thinker, who was educated in the West and spent a long time trying to understand Western civilization and culture. He believed that the decline of Muslims is not because of Islam, but because of Muslims themselves. Belonging to a country (Algeria) that had suffered for 130 years from one of the worst colonial rules in the world, Bennabi looked deep into the essence of the problem to find out if it is mainly a problem of civilization. ${ }^{5}$ Kirat (2014)

The texts written by the leaders of Muslim Scholars Association fall within intellectual, religious texts with moderate, Islamic connotative charge, opposing the French Colonialism at that time. They were written in the 1930s and have continued even after the independence. This association has played a major role in shaping public opinion, and in raising public awareness.

The prose of these scholars has a complicated character that originates from the occurrence of uncommon terms and expressions. This usually requires the use of monolingual dictionaries, such as: يحمي الذّمار and (Tebessi, 2011, p.1156) meaning respectively (They all move together) and (He protects his family and his honor).

In this regard, it could be argued that Arabic language authority at the terminological level imposes specific strategies that belong to foreignization mentioned by Venuti (1995/2003). To apply these strategies, we usually use borrowing or cloning as Bani Amiri (2014) has pointed out ${ }^{7}$. In the following example, we have borrowed the expression: أهل الصّفة (Ahl Assuffah) into French language and added a clarifying translation. Consequently, even if we use foreignization in borrowing, domestication also takes place through the explanation provided in French. This methodical fluctuation in the translation process confirms the idea that translation is an overlap of

Arab World English Journal for Translation \& Literary Studies 
many strategies, according to what is required by the translation situation.

Intellectual texts with a religious character have certain specificities and require extensive research before embarking on translation. In the case of the expression "(أهل الصيّفة (Ahl Assuffah), we first searched for the meaning in Arabic, because the explanation provided by Larbi Tebessi in the extract below, is excessively concise and does not enable us to understand. Moreover, we remained careful even after long search for this concept in religious websites written in French, because many of them spread erroneous and biased information about Islam. Then comparisons were drawn between our readings in specialized books in Arabic and those electronic websites.

\section{Data Analysis}

The first example is centered on the expression "Ahl Assuffah" and how it should be interpreted.

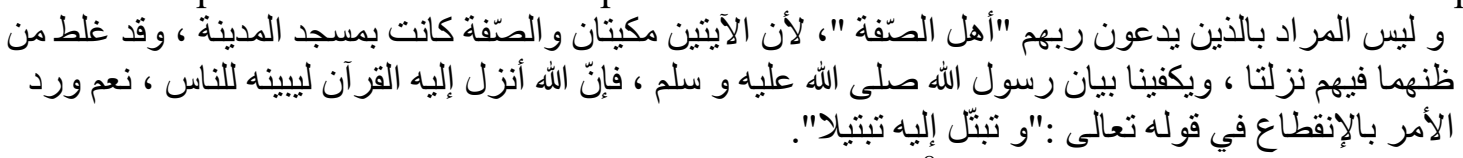

(Tebessi, 2011: p.90 $0^{8}$ )

The author indicates that what is meant by those who pray to God is not "Ahl Assuffah", because the two verses were revealed in Makkah Al-Mukarramah, while "Asuffa ' was situated in the Prophet's Mosque of Al-Madinah Al-Munawwarah, and it is wrong to think otherwise. The Prophet's indication is sufficient evidence as the Quran was revealed to him by God to explain it to people. Devotion to Allah is ordered in verse 8 of the Chapter of Al-Muzzammil (The Wrapped in Garments) "devote yourself to Him with exclusive devotion." "The French translation that we have provided for this is as follows:

Notons que ce verset ne désigne pas les soufis de l'époque qu'on appelait أَهلْ الصُّفَّفِ Aș̣nuffah] «Les gens du banc », puisque il a été révélé à Makkah et non à Medine où se trouvaient ces gens. Il est vrai qu'Allah a révélé le Coran au prophète que la paix et le salut soit sur lui, pour le diffuser à son peuple, comme il est vrai qu'Allah nous a ordonné de l'adorer conformément à ce verset « et consacre-toi totalement à Lui. » Selon plusieurs théologiens islamiques « se consacrer à Allah » signifie : la loyauté. Dans les deux Sahihs, le prophète -que la paix et le salut soit sur lui- avait interdit à Othmane Ibn Mardan de ne s'adonner qu'aux pratiques religieuses.

This translation and explanation suggest that this verse does not refer to sophists of that period who were called "Ahl Assuffah", meaning "people of the porch", because it was revealed in Makkah and not in Al-Madinah where they were living. It is true that God has revealed the Quran to the Prophet -peace and blessings be upon him- to disseminate it to his people, and that we have been ordered by God to worship him in accordance with the verse "Devote yourself completely to him ". According to many Islamic theologians, to devote oneself to Allah means loyalty. In the two Sahihs (books of Hadith by Al-Bukhari and Moslem), the Prophet- peace be upon him- has forbidden Othman Ibn Mardan to devote himself to something other than religious practices.

After the translation was accomplished, another explanation in French available on the web was added, in the belief that addressing French speakers with a style that is common to them, can 
be more efficient to confirm the reasoning and the explanation:

(le mot a donné « sofa » en français), en référence à ceux qui vivaient dans la Mosquée du Prophète à Yathrib (Médine), et qui furent mentionnés dans le Coran comme « la compagnie de ceux qui invoquent leur Seigneur matin et soir désirant Sa face» Al Kahf, verset 28, et qu'on aurait désignés par le mot Suffiyya ${ }^{10}$.

It indicates that the word has produced "Sofa" in French, in reference to those who were living in the Prophet's Mosque in Al-Madinah, who were mentioned in The Holy Quran by " with those who call upon their Lord, morning and evening, seeking His pleasure" (Chapter of Al-Kahf (The Cave): 28) ${ }^{11}$, who would be then called Suffiyya.

In other words, this piece of information is contradictory with what the scholar has meant to introduce. This is considered as a cognitive burden for the translator who finds himself lost between controversial ideas, that require long search and careful scrutinizing to avoid this kind of intellectual contradictions.

In this regard, the question of translatability versus untranslatability is raised, and it is for the translator to adopt specific strategies to achieve his translation goal. Translation in this context was almost unattainable, due to the new ideas included in this book, in comparison with what was prevalent in religious environments in that period. Such terms necessitate research and examination to such an extent that translating one single concept is time consuming. In fact, in spite of the high number of translations, it is hard to find a comprehensive work such as a specialized dictionary or a glossary which gives a detailed account of the terms used in the complicated and delicate field of Islamic studies. Unlike other knowledge fields, Islamic concepts entail meanings that were deeply rooted since the era of the Prophet Mohammad, peace be to him, and are not affected with modern technological factors. To put it another way, these concepts do not imply new meanings over time, at least within the Islamic context.

Another problem was encountered when translating this concept concerning whether it should be linked to the idea of Sufism and its emergence. The author strives to show that the origin of Sufism is not Arabic, because Ahl Assuffah in the Prophet Mohammad's era were not devoting themselves to worship and invocation of God for a religious motive, but rather because they were homeless and found themselves worshiping God in the Prophet's Mosque, especially in this place.

In support of this argument, the author also remarks that the two verses are Makkan, whereas 'Suffa' is related to the Prophet's Mosque 'Almasjed Annabawi' situated in Al-Madinah. One scientist has answered this scholar at that time, explaining that the origin of the word "tassaouf" is from Latin and means wisdom, a piece of information which may be shocking for specialists in Islamic studies, and about which one should be cautious.

Moreover, there are some problematic issues related to romanization ${ }^{12}$ connected with writing Arabic words in foreign languages (Saadane, Semmar, \& Bedjaoui, 2016). It is a term used for the conversion of a word sounds to the writing system of Latin regardless of their 
AWEJ for Translation \& Literary Studies Volume, 3 Number 3. August 2019

The Awakening of Female Consciousness in Kate Chopin's

Alajlan

pronunciation.

Romanization, or Latin transliteration is witnessing a breakthrough due to the significant use of many languages on the web, to cater for the needs for information search across languages, and could be a handy tool in some translation situations especially in religious texts. Nevertheless, it has been subjected to controversy among scholars and researchers. ElShiekh and Saleh (2011) have examined the use of translation and transliteration in Islamic discourse in Western Countries, and some religious terms were analyzed such as God versus Allah, alms-giving versus Zakat ; they argue that it is highly encouraged to use translation even through a general term, for example "praying" instead of Salat/Salaah, as this emphasizes the common elements between religions, produces a positive effect on the target audience, and is connected with a tolerant religious discourse that accepts the other.

According to them, transliteration is a helpful technique when the concept in question is not found in the target culture, or when translating proper nouns. otherwise, they suggest that: " [...]the use of transliteration rather than translation of Islamic religious terms may be more common in the Islamic discourse that adopts an anti-other attitude " (ElShiekh \& Saleh, 2011, p.142).

Similarly, Hassan (2016, p.121) notes that one of the problems related to the transliteration of Islamic religious terms is "that the transliterated form may give a sense of the exotic and cultural difference." However, he mentions many advantages of transliteration, and argues that translation of this type of terms into English is only appropriate when source language items and target language items are cross-culturally equivalent, and have the same referents and connotations, whereas transliteration is strongly recommended in all other situations where SL and TL items are partially-equivalent or non-equivalent (Hassan,2016).

He considers transliteration as being appropriate in the case of proper nouns and culturebound terms with no equivalents, but he maintains that it is compulsory with some words that must be learned by non-Arabic speakers from the Muslim community such as tasbīhah, takbirah, tahmīdah, tahlīlah, tashahhud (Hassan,2016).

As for the case of partially equivalent terms, and unlike the view suggested by ElShiekh and Saleh (2011) mentioned above, he argues that transliteration enhanced by explanations within footnotes is more appropriate than translation. The referents shared by (SL) and (TL) terms are similar while the connotations are different, such as in Salaat/prayer, Alhajj /pilgrimage. Thus, transliteration is believed to preserve accuracy and readability, and to avoid any loss in meaning, and the transliterated forms introduced into the target language will be assimilated over time, (Hassan,2016), although the target audience may not fully grasp their meanings immediately.

Another issue linked to the use of transliteration systems especially romanization, is the declining standards in their application by some authors, like errors and inconsistencies appearing in the use of symbols, for example the Arabic letter ayn (') and the hamzah (') which lead to confusion ( Gul, 2018). In order to reduce the amount of transliteration errors and maintain more 
accuracy and consistency, $\operatorname{Gul}(2018$, p.9) suggests the adoption of what he refers to as "generally agreed-upon symbols "or using the transliterated system taken from a reliable dictionary. He believes that transliteration plays a significant role in academic publications, shows the difference between Arabic words which have the same spelling in the Latin script, and are dissimilar in their diacritics such as $\mathrm{Kha}^{-}{ }^{-} \mathrm{iq} / \mathrm{Khal}^{-}{ }^{-} \mathrm{q}$, as well as enables the author to preserve the meaning of a given concept in a language other than Arabic (Gul, 2018).

In our opinion, this implies that with some Islamic concepts, translation may not be an efficient tool to completely convey the meaning, whereas transliteration, which could be considered as part of foreignization, has more capacity to render the meaning.

An undeniable example on inconsistency in the use of transliteration systems is available when we examine the Roman script of the word 'Assuffa' stated above. Three different ways are possible: «sofa», al-soufa, as-suffa. Such scripts may give rise to ambiguity for the translator who wonders about how to select one of the forms produced by the transliteration mode. In such cases, an explanatory translation, a paraphrase, or a footnote for the word that is alien to the target language is usually provided.

Along with those strategies, we had also turned to the reductionist translation when hadith chain of transmission was used. We have summarized by saying "according to many scholars". The adoption of this style is related to the nature of the target language, which is French, where hadith transmission is inexistent. This leads us to resort to summarizing, because the focus is on what is said and not who said it. This strategy could be included within what is called domestication. It is an attempt to adapt the new text with the receiving culture.

In the same context, we have experienced the translation of what was translated before such as Conditions de la renaissance (Conditions of Renaissance) of Bennabi. In fact, we were invited by the Algerian publishing house 'Ben Merabet' to retranslate this book. This need has emerged at the request of Algerian readers, who were seeking a new Arabic version after the one produced in 1957 by the Syrian Publishing House, as mentioned above. This points to changes witnessed by Arabic language over time in the Arab world, and its relationship with translation. This is an important issue but goes beyond the scope of this study.

\section{Translation and Rewriting}

Before starting the translation, we have carried out an examination of the translations accomplished by the Egyptian scholar A. Shaheen, but it was perplexing to see the significant number of deviations from the source text. This may suggest that he was not translating but rewriting it, using additions and omissions which may be related with what was described by Butt (2009) as "a modern woman's confrontation with the [...] perception of Islam, on the one hand, and the idea of Islam as an absolute truth, on the other" (Butt, 2009, p. 168). Thus, many hypotheses could be formulated. Firstly, Bennabi was the friend of Shaheen and was summarizing his ideas to him, then Shaheen turns to rewrite them. Secondly, he has suggested to him what to write, regarding the specificity of Arabic and the Arab community at that time, for fear of shocking

Arab World English Journal for Translation \& Literary Studies 
the Arab readers with his ideas. It is hard to confirm or refute these hypotheses owing to a lack of research about the translations of Bennabi's books. However, the following example may give a clear picture. The ST is in French, the two translations to be discussed are in Arabic, and the English version is added to ST, TT1, and TT2 by authors for the sake of clarification.

Table 2. Comparison between our Translation and Shaheen's Translation

\begin{tabular}{|c|c|c|}
\hline $\begin{array}{l}\text { The Source Text: } \\
\text { Le problème de la femme }\end{array}$ & $\begin{array}{l}\text { Our Translation } \\
\text { قضية الدرأة (qadiat } \\
\text { almar'a) } \\
\text { [The Woman's } \\
\text { Issue] }\end{array}$ & $\begin{array}{l}\text { Shaheen's Translation } \\
\text { مشكلة الدرأة ( mushkilat almar'a) } \\
\text { [The Woman's Problem] }\end{array}$ \\
\hline $\begin{array}{l}\text { Ce langage semble } \\
\text { encore établir une sorte } \\
\text { d'égalité quantitative } \\
\text { entre les deux individus } \\
\text { constitutifs de l'espèce } \\
\text { humaine. Mais il n'y a } \\
\text { pas d'égalité cependant } \\
\text { entre deux éléments qui } \\
\text { ne sont interchangeables } \\
\text { ni dans l'ordre } \\
\text { biologique, ni dans } \\
\text { l'ordre sociologique. } \\
\text { L'homme a créé des } \\
\text { chefs-d'œuvre que le } \\
\text { génie féminin n'aurait pu } \\
\text { enfanter. Mais la femme } \\
\text { a enfanté l'homme. } \\
\text { A vrai dire, quand on } \\
\text { parle de la femme et de } \\
\text { l'homme, on ne parle pas } \\
\text { de deux choses, mais } \\
\text { d'une seule, d'une unité } \\
\text { dans laquelle on n'a pas } \\
\text { le droit de dire qu'une } \\
\text { partie est "inférieure", } \\
\text { "supérieure" ou "égale" à } \\
\text { l'autre. } \\
\text { Une semblable } \\
\text { comparaison supposerait } \\
\text { non seulement la } \\
\text { connaissance d'un } \\
\text { dénominateur commun, }\end{array}$ & 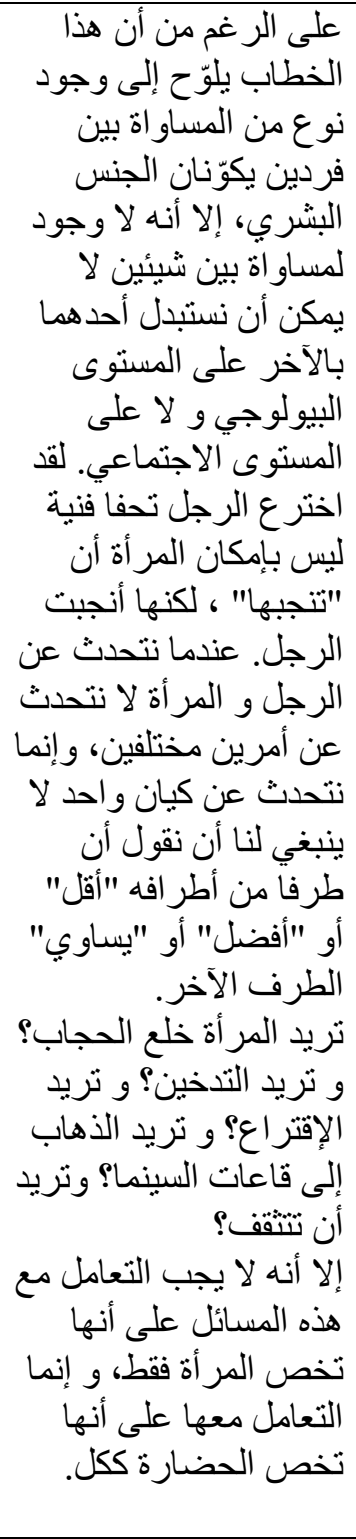 & 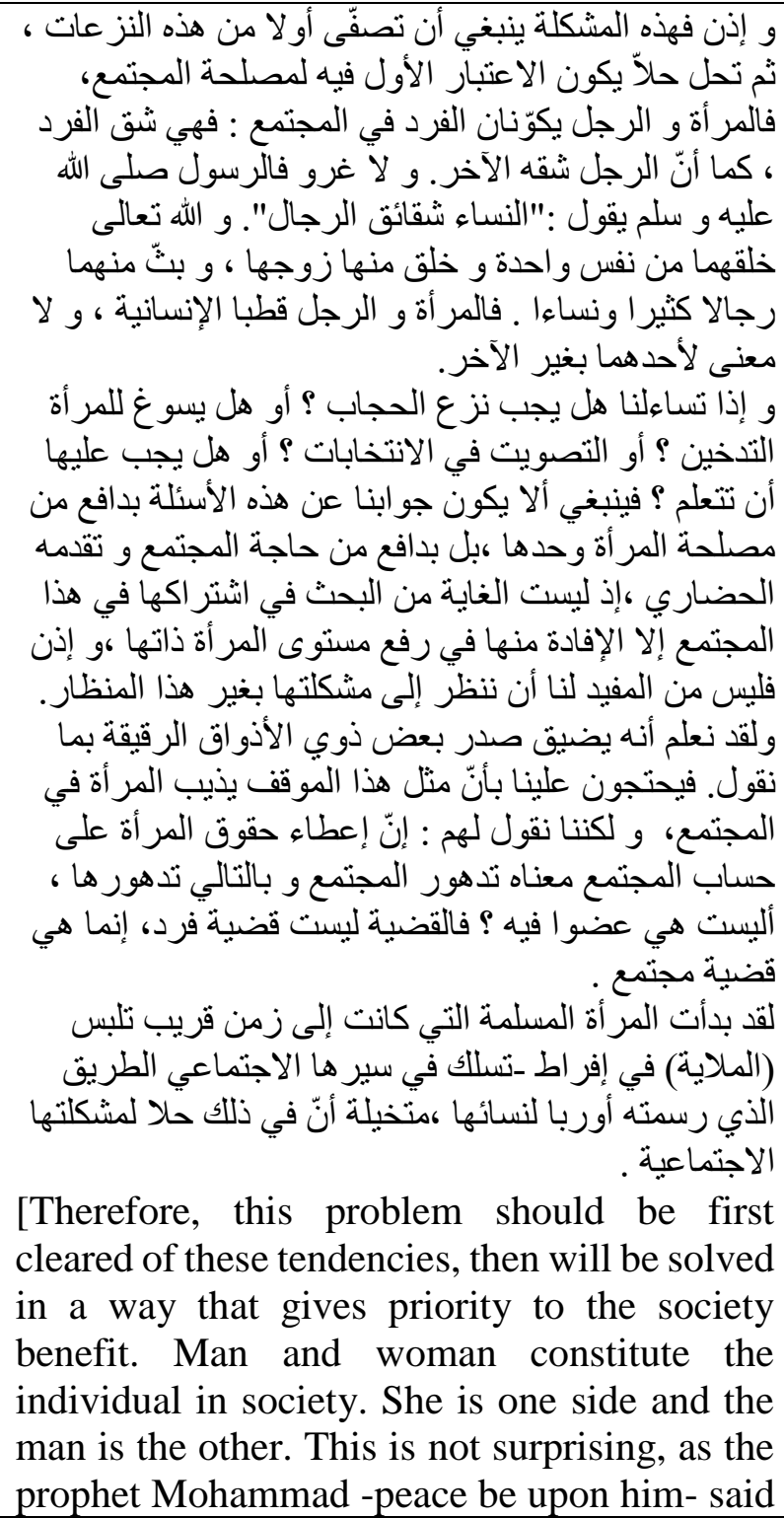 \\
\hline
\end{tabular}

Arab World English Journal for Translation \& Literary Studies 
AWEJ for Translation \& Literary Studies Volume, 3 Number 3. August 2019

The Awakening of Female Consciousness in Kate Chopin's

Alajlan

\begin{tabular}{|c|c|c|}
\hline $\begin{array}{l}\text { qu'on pourrait au besoin } \\
\text { nommer le "couple", } \\
\text { mais d'un numérateur } \\
\text { qu'on ne saurait } \\
\text { déterminer dans le cas } \\
\text { général. } \\
\text { Par conséquent, il } \\
\text { faudrait faire justice dans } \\
\text { notre esprit de toute la } \\
\text { littérature féministe, afin } \\
\text { de poser sainement ce } \\
\text { problème. } \\
\text { Celui-ci ne se pose pas } \\
\text { pour une catégorie, une } \\
\text { classe, un sexe, mais } \\
\text { pour la société humaine, } \\
\text { son avenir et sa } \\
\text { civilisation. } \\
\text { La femme veut jeter le } \\
\text { voile? Elle veut fumer? } \\
\text { Voter? Elle veut aller au } \\
\text { cinéma ou s'instruire? } \\
\text { Il ne s'agit pas de poser } \\
\text { de telles questions "pour" } \\
\text { la femme, mais "pour" la } \\
\text { civilisation. } \\
\text { [It seems that this } \\
\text { language still establishes } \\
\text { a kind of quantitative } \\
\text { equality between the } \\
\text { two individuals who } \\
\text { constitute the society. } \\
\text { However, there is no } \\
\text { equality between two } \\
\text { components which are } \\
\text { interchangeable, neither } \\
\text { at the biological, nor at } \\
\text { the social levels. Men } \\
\text { have the } \\
\text { masterpieces that the } \\
\text { genius of women could } \\
\text { not have conceived, but }\end{array}$ & $\begin{array}{l}\text { [Although this } \\
\text { discourse implies } \\
\text { the existence of a } \\
\text { kind of equality } \\
\text { between two } \\
\text { individuals who } \\
\text { constitute the } \\
\text { human race, there is } \\
\text { no equality between } \\
\text { two things that are } \\
\text { interchangeable } \\
\text { neither at the } \\
\text { biological, nor at } \\
\text { the social levels. } \\
\text { Man has designed } \\
\text { masterpieces that } \\
\text { the woman cannot } \\
\text { create, but she gave } \\
\text { birth to man. When } \\
\text { we talk about man } \\
\text { and woman, we are } \\
\text { not speaking about } \\
\text { two different things } \\
\text { but rather one } \\
\text { entity. We should } \\
\text { not say that one of } \\
\text { its parts is inferior, } \\
\text { superior, or equal to } \\
\text { the other. } \\
\text { Do Women want to } \\
\text { take off the veil? to } \\
\text { smoke? to vote? to } \\
\text { go to the cinema, to } \\
\text { receive education? } \\
\text { Nonetheless, we } \\
\text { should not deal with } \\
\text { these issues as } \\
\text { being } \\
\text { merely to women, } \\
\text { but to civilization as } \\
\text { a whole]. }\end{array}$ & $\begin{array}{l}\text { : "women are the sisters of men." } \\
\text { God has created them from one soul and told } \\
\text { us about this by saying: O men! Fear your } \\
\text { Lord Who created you from a single being and } \\
\text { out of it created its mate; and out of the two } \\
\text { spread many men and women. Chapter of An- } \\
\text { Nisaa, verse } 1^{13} \text {. } \\
\text { Man and woman are the main components of } \\
\text { humanity; we cannot have one without the } \\
\text { other. } \\
\text { If we question whether the veil should be } \\
\text { removed, or can the woman be allowed to } \\
\text { smoke, or to vote? or is she required to get } \\
\text { educated? the answer should be based on the } \\
\text { benefit of women as well as the society needs } \\
\text { and civilizational progress. } \\
\text { The endeavor to involve women in the society } \\
\text { aims to uplift women themselves; thus, it is } \\
\text { useless to view their problem differently. } \\
\text { This may upset some sensitive people. They } \\
\text { argue that this attitude melts women into the } \\
\text { society, but we think that giving rights to } \\
\text { women at the expense of society means its } \\
\text { decline, then the deterioration of woman's } \\
\text { situation as it belongs to it. It is not an } \\
\text { individual's issue but a social issue. } \\
\text { The Muslim woman who was until recently } \\
\text { overusing the 'melaya ' (a long and large black } \\
\text { cloth which covers the whole body), has } \\
\text { started to follow the path set up by Europe for } \\
\text { its women, thinking that it will solve her social } \\
\text { problem]. }\end{array}$ \\
\hline
\end{tabular}

Arab World English Journal for Translation \& Literary Studies

ISSN: 2550-1542 | www.awej-tls.org 


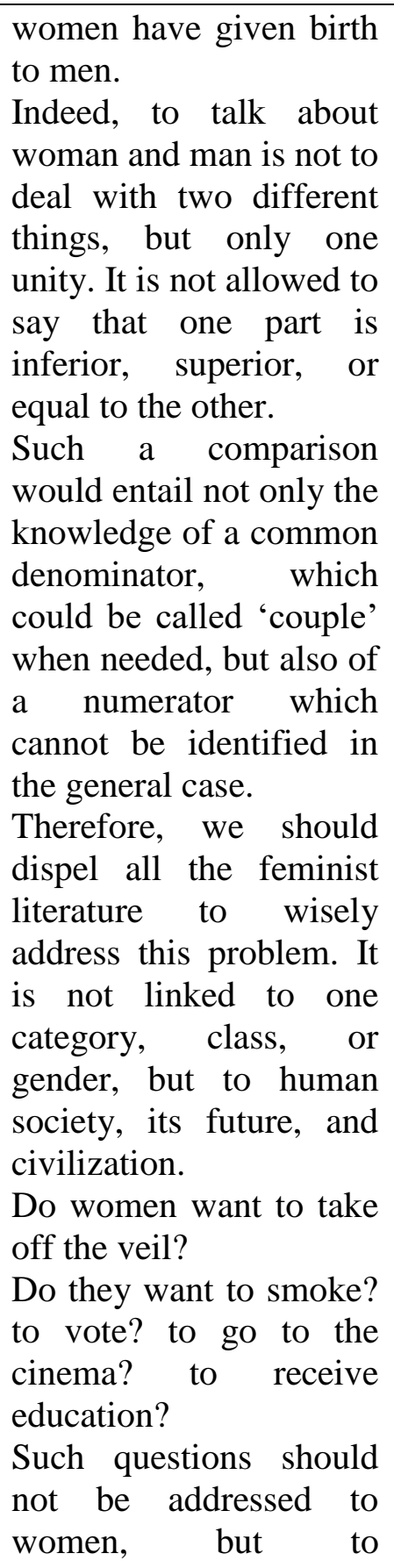

Do women want to take off the veil?

Do they want to smoke? to vote? to go to the cinema? to receive education?

Such questions should not be addressed to women, but to civilization].

The initial analysis and comparison of these translations reveal that the method used in each case is totally different: Shaheen tends to use adaptation in his translation, for example, when he added a koranic verse and a Prophetic Hadith to justify his opinion. It could be suggested that he expresses not Bennabi's point of view, but rather his own ideas as an Islamic intellectual with 
a specific orientation. Moreover, because Bennabi is an engineer who uses mathematical equations to transmit and justify his thoughts, the French (source) text is characterized by direct and clear style, and solid arguments are put forward. An interrogative sentence where Bennabi wonders about the status of the Algerian woman, compared to that of the European woman, is omitted from Shaheen's translation:

S'agit-il, en particulier, de faire de l'Algérienne la semblable de sa sœur européenne?

(Bennabi, 1948/2005, p.124)

Is it a question of making the Algerian woman similar to her European sister?

(Our translation)

Shaheen has substituted the Algerian woman with the Muslim woman, has elaborated on this idea, and changed the sentence form from interrogative to affirmative. Thus, he shifted the text to a spiritual level supported by argumentative evidence from the Quran, Sunnah, and the intellectual approach that he adopts as an Islamic thinker. It could be noticed from his translation that the woman is under social pressure. An observer governs all her behaviors, either it is the man or the society where she lives. Meanwhile, Bennabi describes her as having free rein to make decisions, and as the source of equilibrium for the Muslim community.

What is more is Shaheen's Arabic translation of the title which we consider as a firstdegree cultural problem. Although Bennabi has a froncophone culture, his Arab identity which regards women as a barrier to social development, could be perceived, but is seen only from the title which compares the woman to a problem. Shaheen has followed the same path which may suggest that discussion about women is related to instinct, femininity, and emancipation, in a way that goes beyond the source text. Thus, this may confirm and reinforce some representations which portray women as the cause of social collapse.

We suggest using “issue” قضية (Qadiyyah) or 'question' (مسألة), instead of “problem” مشكلة (Mushkilah), as it reflects in our opinion the woman's status in Arab societies. She faces negative stereotypes every day and attempts to fight them with all her strength. Furthermore, the word 'problem 'refers to chaos which prevents women from claiming their rights and implies a pejorative connotation. Instead, the word "issue" allows them to struggle for these rights.

\section{Conclusion}

This study aimed to explore the problematic issues related to the translation of intellectual and religious texts, and the major difficulties that hamper the translator in doing his task. Translators swing between domestication and foreignization, transliteration and adaptation, as well as objectivity and subjectivity, to bring forth what is more or less close to the source text. In all that, some uncontrollable external factors affect the translator's conscious and unconscious choices. We have discussed the language authority emerging from cultural and religious authority ${ }^{14}$ in the texts of scholars who belong to the Association of Muslim Scholars. We have also raised the issue of translators' linguistic preferences, and how specific terminology is imposed by some institutions, mainly when working with international organizations which adopt specialized glossaries. In spite 
of this, it can be argued that using objectivity in rendering information that is crucial in shaping the Arab community thought is of high importance, and the translator should attempt to use invisibility that was mentioned by Venuti (1995/2003), for keeping the text free from any ideological character.

While our results apply to a particular type of texts, namely intellectual and /or religious texts, other areas in Arabic translation studies need to be further explored.

\section{NOTES}

${ }^{1}$ Bedjaoui has attended this conference on December 13-14, 2017 by presenting a paper entitled [The French Translation of Religious and Intellectual Concepts: Translatability Vs. Untranslatability], which was published as part of the conference proceedings ( 4 Translation and the Problematics of Crosscultural Understanding 4, Doha, December 13-14, 2017 ,The Forum for Arab and International Relations.) Bedjaoui has also addressed the issue in a conference held by ESIT, France, in November 2017 on the translator's challenges.

${ }^{2}$ This topic was the title of Dr.Imene Benmohamed's presentation during the International Conference, held by the High Arab Institute for Translation on December2016, Algeria .The Iranian interpreter has conveyed his country's ideology through his official position.

${ }^{3}$ This is our translation of the following extract from an Arabic article of Zouaoui B. (2002/2012, p.13):

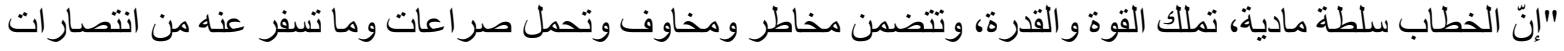

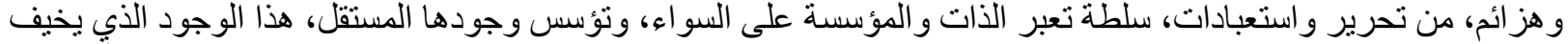

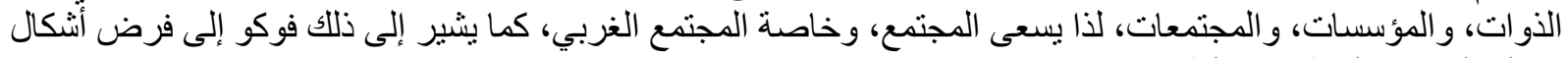

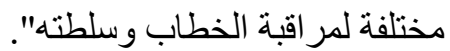

4 'Essays of Algerian Muslim Scholars Association' is our translation for the original name in Arabic: مقالات جمعية العلماء المسلمين الجز ائريين.

${ }^{5}$ Kirat, M. (2014): Malek Bennabi on Question of Ideas. The Peninsula. (27 October2014) https://search-proquest-com.sdl.idm.oclc.org/docview/1616394040?accountid=142908.

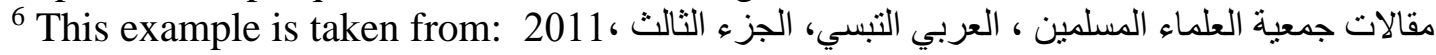

[Tebessi, L. (2011). Essays of Muslim Scholars Association, Part 3].

${ }^{7}$ A lecturer at the University of Algiers II, Algeria, who has recently suggested this term.

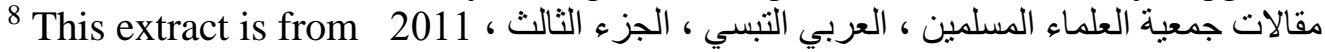

[ Tebessi, L. (2011). Essays of Muslim Scholars Association, Part 3].

${ }^{9}$ The translation of the first part -verse 8, Chapter of Al-Muzammil is from: http://www.islamicstudies.info/tafheem.php?sura=73-

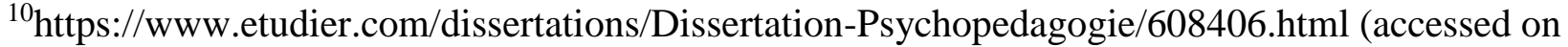
July 15, 2018).

11 The translation of part one- verse 28, chapter of Al-Kahf is from http://www.islamicstudies.info/tafheem.php?sura=18\&verse=27\&to=31

سعدان هدى، سمار نصر الدين ، بجاوي وفاء،" استخدام الرومنة لتحسين الربط بين الكلمات في المدونات المتوازية" مجلة 12 2016، 2016) Using Romanization to Improve Linking between Words in Parallel Corpora. Fittarjamah. Annaba.]

Arab World English Journal for Translation \& Literary Studies 
AWEJ for Translation \& Literary Studies Volume, 3 Number 3. August 2019

The Awakening of Female Consciousness in Kate Chopin's

Alajlan

${ }^{13} \mathrm{http}: / / \mathrm{www}$.islamicstudies.info/tafheem.php?sura=4

${ }^{14}$ Authority, as explained in a previous section, means the power of language that imposes specific contextual choices.

\section{About the authors}

Wafaa Bedjaoui is currently an Associate Professor at Princess Nourah University in Saudi Arabia. She is the author of several translations from French into Arabic such as I"The Bible and Colonialisml" by Michael Prior, and has published different papers in the field of Translation Studies and Sociolinguistics. She is also the coordinator of the Algerian journal devoted to translation studies \"Cahiers de traduction।". ORCID ID: https://orcid.org/0000-0002-0660-8418

Amina Tahraoui is an Assistant Professor at Princess Nourah bint Abdulrahman University. Her research interests include Translation and Interpretation Teaching Strategies, Curriculum Development, Cognitive linguistics and Neurolinguistics. Her great focus is on research that contributes to a deeper understanding of brain processes involved in learning, and how does this affect the training of translators and interpreters. ORCID ID: https://orcid.org/0000-0002-4214$987 \mathrm{X}$

\section{References}

Bedjaoui, W. ترجمة المفاهيم الدينية الفكرية إلى اللغة الفرنسية بين القابلية و الإستحالة. (2018) .

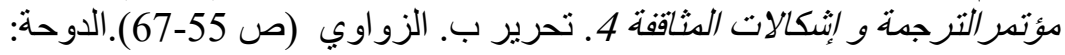
منتدى العلاقات العربية و الدولية.

[The French Translation of Religious and Intellectual Concepts: Translatability Vs Untranslatability. In B. Zouaoui (ed.), Translation and the Problematics of Cross-cultural Understanding 4 (pp.55-67). Doha: The Forum for Arab and International Relations.

Bennabi, M. (1948/2005). Les conditions de la renaissance. Algiers: ANEP.

Bennabi, M. (1957). Shurut Al-Nahdah (in Arabic, translated from French by A. Shaheen). Dimashq: Dar el Fiqr.

Butt, N. (2009). Negotiating Untranslatability and Islam in Leila Aboulela's the

Translator. Matatu, 36,167-179. Available at https://search-proquestcom.sdl.idm.oclc.org/docview/757071612?accountid=142908

ElShiekh, A. A. A. \& Saleh, M. (2011). Translation versus Transliteration of Religious Terms in Contemporary Islamic Discourse in Western Communities. International Journal of English Linguistics, 1, (2), 141-147. https://doi:10.5539/ijel.v1n2p141.

Gul, A. (2018). The Declining Standards of Arabic-to-Roman Transliteration in Academic Writing, Editing, and Publishing. Publishing Research Quarterly,34 ,(1)1-10. https://doi.org/10.1007/s12109-018-9566-3.

Hassan, S. (2016). Islamic Religious Terms in English - translation vs. transliteration in Ezzeddin Ibrahim and Denys Johnson-Davies' translation of An-Nawawī's Forty Hadīths. Translation \& Interpreting, 8, (1) ,117-132.

DOI: 10.12807/ti.108201. 2016.a08.

Islamic Studies.info (2015): Tafheem.net. Towards Understanding the Quran, Available at http:// www.islamicstudies.info/tafheem.php. (accessed August 22, 2018). 
Kirat, M. (2014, October 27). Malek Bennabi on Question of Ideas. The Peninsula, Available athttps://search-proquest-com.sdl.idm.oclc.org/docview/1616394040?accountid=142908.

Saadane, H., Semmar, N., \& Bedjaoui, W. (2016) استخدام الرومنة لتحسين الربط بين الكلمات في المدونات المنو ازية. في الترجمة.

[Using Romanization to improve linking between Words in Parallel Corpora]. [ fittarjamah]. Annaba. 3, (1) ,28-43. https://www.asjp.cerist.dz/en/article/5525

Tebessi, L. (2011). مقالات علماء جدعية العلماء المسلمبن الجزائربين: مقالات العربي التبسي [Larbi Tebessi Essays: Essays of Scholars of The Association of Algerian Muslim Scholars]. Ain M'lila: Dar el Houda, part 3.

Venuti, L. (1995/2003): The Translator's Invisibility ,Available at https://www-taylorfranciscom.sdl.idm.oclc.org/books/9781134820795

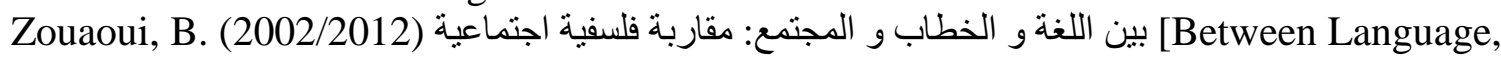
Discourse, and Society: A Social Philosophical Approach]. Insaniyat, 17/18, 33-57. Published online 30 September 2012, retrieved January 19, 2018 from http://journals.openedition.org/insaniyat/8643; DOI: 10.4000/insaniyat.8643. 